\title{
GREEN MARKETING PRACTICES: GREEN BRANDING, ADVERTISEMENTS AND LABELLING AND THEIR NEXUS WITH THE PERFORMANCE OF SMES IN SOUTH AFRICA
}

\author{
REGINALD MASOCHA
}

School of Economics and Management, University of Limpopo, Sovenga 0727, South Africa.

*Corresponding author: reginald.masocha@ul.ac.za

Submitted final draft: 27 April $2020 \quad$ Accepted: 1 December 2020

http://doi.org/10.46754/jssm.2021.01.015

\begin{abstract}
The perilous nature of human activities over the planet earth is a central issue from both the public and academic perspectives. Shifting customer behaviour towards pro-environmentalism has been equally attributed as embedding the green revolution prevailing in the business world. Confronted by an endangered widespread system due to brittle planet earth demanding environmental responsibility behaviour from its inhabitants, interrogations exist on the subsequent impact on the overall performance of businesses when they assume green virtues. The study investigated three independent variables (eco-branding, eco-labelling, and environmental advertisements) as green marketing practices with firm performance being a dependent variable. The research objective was to determine how eco-branding, eco-labelling as well as environmental advertising relate to firm performance on Small and Medium Enterprises (SMEs) in Polokwane, Limpopo Province of South Africa. Convenience sampling was utilised to select a sample size of 156 participants from the Limpopo province of South Africa. A self-administered questionnaire was used in gathering data and the structural equation modelling through AMOs version 25 was applied in analysing the collected data. The research established that all the independent variables had significant nexuses with firm performance. Thus, recommendations are made for SMEs to consider green marketing practices as they impact positively on their subsequent firm performance.
\end{abstract}

Keywords: Green Marketing, eco-branding, eco-labelling, environmental advertisements, firm performance.

\section{Introduction}

The phenomenon of green marketing emerged to prominence during the 1980 s and has since grasped the interests and attention of latent researchers in the management sciences. The American Marketing Association (AMA) convened for the first time about the concept of ecological marketing in 1975, while the year 1980 marked the emergence of the term green marketing (Yazdanifard \& Igbazua, 2011; Durmaz, \& Yaşar, 2016). Attune to global sustainable development aspirations, guidelines, and practices, ever-increasing demands for businesses to examine their business practices and their aftermaths towards the environment have been witnessed (Masocha \& Fatoki, 2018; Carvalho et al., 2019). Meanwhile, there is an upsurge scale of firmness impelled by climate changes reiterating that the earth's inhabitants need to consciously utilise practises and resolutions that are environmentally competent (Carvalho et al. 2019). Consequently, businesses all over the world are increasingly embracing green marketing practices in response to these demands (Fuentesa, 2015; Simãoa \& Lisboa, 2017). However, the specific implications of embracing green marketing practices persist to be somewhat incomprehensible amongst marketing practitioners and policymakers of present firms principally on the nexus of specific green marketing strategies and the performance of businesses (Eneizan \& Wahab, 2016). The growing demand for firms to go green is heightening competition subsequently increasing worries amongst firms concerning the inherent value or detrimental impact on their performance (Eneizan \& Wahab, 2016)

Green marketing is commonly defined as 
integrating the marketing discipline, public policy processes together with the natural environment and constitutes the selling of products and services on the premises of their benefits towards the environment (Medhi, 2015). Green or environmental marketing is deemed to constitute all undertakings intended to produce and enable exchanges aimed at the satisfaction of human needs and wants with a minimal detrimental impact to the environment (Joshia \& Rahman, 2015). In latent literature, the terms green marketing and environmental marketing, ecological marketing, or sustainable marketing are often interchangeably used (Hasan \& Ali, 2015; Masocha, 2018). Contemporarily, there is a definitional dilemma amongst marketing practitioners and consumers at large about the phenomenon of green marketing (Carvalho et al., 2019). Regardless of the definitional dilemma, what is apparent in the contemporary business world is that consumers' demand for green products has recently reached unprecedented levels with sporadic signs of agitation and unyielding posture towards nongreen practice in the future (Negassa, 2015). Firms linked to unethical business practices or operations which damage the environment are being increasingly boycotted by consumers (Negassa, 2015). In the same regard, researchers, academics, and managerial practitioners are still baffled about how to create an appropriate green marketing offering that is visible and profitable (Fuentesa, 2015). Businesses on another angle are concerned that only a small number of these people are willing to purchase these green products at a premium (Sreen et al., 2018).

Green marketing is largely concerned with formulating and utilising strategies and practices that lead to the achievement of strategic and profitability goals of a firm, predominantly about the reduction of negative or improving positive impact on the ecological environment (Eneizan \& Wahab, 2016). By greening their marketing practices, firms are poised to experience numerous benefits, inter alia, security against regulations, satisfying green consumer needs and expectations, gain a green competitive edge against their counterparts, or transforming their entire business philosophy and image (Medhi, 2015; Simãoa \& Lisboa, 2017). In latent literature, numerous apparent advantages are emanating from green practices, namely, improved corporate image, waste reduction, lower costs, high customer satisfaction, improved efficiency, enhanced goodwill, growing market share, as well as profitability (Hasan \& Ali, 2015). Coherently, marketing literature highlights some of the gains of following green inventiveness, namely, superior financial increases and market share, more employee commitment, improved firm performance, and heightened capabilities (Eneizan \& Wahab, 2016). Notwithstanding the proliferation of sustainability issues amongst corporations, satisfactory empirical studies still need to be conducted about green activities and the performance of SMEs (Eneizan \& Wahab, 2016).

Research must be channelled towards SMEs considering their renaissance as economic engines towards economic growth, employment creation, poverty alleviation in many economies across the globe (Hamann et al., 2017; Masocha $\&$ Fatoki, 2018). SMEs have been regarded to be at the backbone of the South African economy (Rungani \& Potgieter, 2018). Although there is voluminous literature concerning green practises, much of it is centered on large corporations (Hamman et al., 2017). As such, there is a need to investigate the phenomenon of green marketing practises towards SMEs since small businesses face institutional and structural conditions that are different from their counterpart large corporations (Masocha \& Fatoki, 2018). Furthermore, there is an existing incessant gap between green attitudes and green consumption to the extent exacerbated by a growth in the number of people prepared to buy green products, with little evidence suggesting a relative growth in the purchase of green products has also grown (Joshi \& Rahman, 2015). In South Africa, most SMEs are constrained regarding the provision of sustainable products due to an increase in the cost of the production process and other difficulties associated with green business operations (Lekhanya, 2014). Faced 
with this plethora of challenges in going green the major question that needs to be answered is on the effect of adopting green marketing on the performance of SMEs. On this backdrop, the primary objective of this study was to establish the nexus between green marketing practices and the performance of SMEs in South Africa.

\section{Overview of the concept of green marketing}

As society's apprehension for the natural environment has spiralled over the preceding decades, businesses worldwide are similarly presented with pressures and obligations about environmental cognisance (Govender \& Govender, 2016). Eventually, as pressure has been mounting towards businesses to be cognisance and accountable for the environmental consequences of their activities, green marketing has developed to be a notion that is anticipated as an impending moral responsibility (Govender \& Govender, 2016). Simultaneously, the green marketing strategy (GMS) has increasingly pervaded academics in latent research. Thus, various stakeholders such as customers, suppliers, government, and society need to actively impose pressure on firms to adhere to green practices in the marketing process (Handayani \& Prayogo, 2017). The strategy is regarded as the business's resolute orientation towards developing procedures and practices that align corporate and marketing objectives with the protection of the natural environment in line with customers' perceptions on sustainable marketing (Govender \& Govender, 2016).

By definition, green marketing is a process of coming up with products and services, utilising promotions that result in customer satisfaction for customers who desire products and services of high quality and performance offered at convenient prices without simultaneously causing detrimental effects towards the environment (Handayani \& Prayogo, 2017). From the American Marketing Association (AMA) definitional perspective green marketing involves the integration of environmentally friendly activities such as product adjustments, operations modifications, packaging, promotional strategies, and awareness creation amid industries (Yazdanifard \& Igbazua, 2011). Consistently, latent research significantly postulates that customers are deeply involved pertaining to environmental matters which emanates from rising environmental mindfulness (Yazdanifard \& Igbazua, 2011). As such, the phenomenon of green marketing is a consequence of firms responding to environmental concerns by consumers (Oattman, 2011).

Since assertions have been made concerning the nexus between consumption and greenhouse gas emissions, the focus has been placed on green consumers as a target market (Guckian et al., 2017). Green consumers are concerned with products that have minimal or no adverse consequences on the environment and being prepared to acquire them even at premium prices (Mahapatra, 2013). Consequently, the profitability of green consumerism fuelled green claims and greenwashing as firms sought to profiteer from the preparedness of consumers to make purchases at relatively higher prices (Chen et al., 2019). Greenwashing relates to marketers utilising uncorroborated or deceptive claims regarding the environmental virtues 'being green' within their products, services, or business activities (Wahba, 2012; Chen et al., 2019). Contrary to genuinely greening their products, firms barely transformed products which they deemed to be green and offered their regular products at the habitual lower costs. Consequently, the existence of genuine green consumers became questioned with some suggestions inclined towards the unpreparedness of customers to pay above normal prices for green efforts (Peattie \& Crane, 2005).

The economy of South Africa promotes green activities, regulations, and laws are passed to ensure that the environment is protected for both the current and future generations (Muposhi, 2019). The vision for a green economy for South Africa is enshrined in the National Framework for Sustainable Development (NFSD), which is premised on various thematic dimensions. 
The NFSD encompasses sustainability in environmental responsibility, production and consumption, water management, transport and infrastructure, efficient and clean energy, waste, buildings, resource management, agriculture, food production, and forestry (Muposhi, 2019). Thus, firms must adhere to these regulatory requirements and develop strategies to communicate with their customers concerning environmental issues (Kanonhuwa \& Chimucheka, 2014).

In November 2011, the government launched South Africa's Green Economy Accord which is a significantly wide-ranging social treaty on green jobs in economic activities covered in the above nine thematic dimensions outlined in the NFSD as well as bio-fuels and ecotourism (Economic Development Department, 2011). Furthermore, this Accord is accompanied by revelations that assist in establishing the premises for a sustainable tomorrow for the entire South African community and their subsequent interaction in the green technological revolution globally. It is evident that the government is not silent on these issues, this means there is more pressure on businesses to change their way of doing things because customers are changing their buying behaviours.

The theoretical lens of the NaturalResource-Based View (NRBV) theory by Hart (1995) provides the basis for this study. Hart postulated the NRBV based on the insights of the traditional Resource Based View (RBV) which is utilised to explain the impact of the firm's unique resources and capabilities towards firm performance and competitive advantage (Ramon-Jeronimo, Florez-Lopez \& AraujoPinzon, 2019; Ferreira, \& Fernandes, 2017). The NRBV makes a significant contribution by encapsulating the constraints emanating from the natural environment which was missing in the classical RBV (Fowler \& Hope, 2007). According to the NRBV theory, pollution prevention, product stewardship and sustainable developments are essential elements that should be integrated into the firm's capabilities and resources to enhance the performance of firms
(Hart, 1995; Fowler \& Hope, 2007; McDougall, Wagner \& MacBryde, 2019). Herein, the study will make empirical contributions towards NRBV by validating the relationship between firm performance and eco-branding, ecolabelling as well as environmental advertising. Eco-branding, eco-labelling, and environmental advertising are strategic issues that are included under the natural environment which are expected to make a positive contribution towards firm performance within the context of SMEs.

\section{Green Marketing and SMEs}

Firms consider environmental marketing as providing the impetus in the achievement of their corporate objectives and aspirations. However, it is paramount that green marketing becomes acculturated into the firm by being prominent in the mission and vision as well as being engraved in the core values and principles of the firm (Emery, 2012). Firms that desire to be effectively green need to ensure that availing of green products is an integrative obligation of all departments prevailing in a firm, rather than letting marketing alone. Herein, green products inherently have the potential to enable firms to distinguish their brands and position in their relative markets (Wahba, 2012). Furthermore, green production, green distribution, and green marketing activities have been noted to contribute towards creativity and efficiency, profitability, and lower product life cycle costs (Ottman, 2011). Waste management undertakings such as recycling, re-use, or sale of processed or unprocessed waste substances can also contribute towards efficiency, profitability, and cost-effectiveness (Durmaz \& Yaşar, 2016). Adopting green marketing practices has various benefits, namely, enhanced health and safety of workers, consumers tend to enjoy products that do not pose health threats during the use of a sustainable product, customers tend to enjoy their lives in their communities without any form of air and sound pollution and other externalities, as well as, preservation of the environment especially for younger generations (Ottman, 2011). However, there is still a wide 
research gap arising from incongruences about the impact on firm performance of going green (Hari Adi \& Adawiyah, 2018).

Drawing from extant marketing management literature, it is submitted that firm performance is directly dependent on proficient marketing practices (Fraj-Andrés et al., 2009). The executions of good marketing practices attach superiority to firms' activities and fortify the competitiveness and market share of the firm. However, about their effectiveness in green practices, SMEs are constrained by inherent characteristics such as limited resources that include skills, finances, know-how, as well as no expertise in green issues (Amegbe et al., 2017) perhaps owing to them being primarily familyowned (Hamann et al., 2017). Furthermore, there is relatively less pressure that is imposed on SMEs by customers towards being green compliant (Hamman et al., 2017). On the contrary, many large business organisations export operation activities to developing nations, which practically exempts them of many obligations in their home countries. In some of the developing nations, large corporations are known of being involved in non-green practices such as natural resource misuse which eventually exhibits negatively on the image of the large corporations (Belz \& Peattie, 2010).

Latent literature contains numerous considerations underpinning the proliferation of green marketing amongst existing firms across industries, with SMEs included. Going green is being increasingly deemed a moral obligation (Belz \& Peattie, 2010), increasing government regulations (Masocha \& Fatoki, 2018), competitors' environmental orientation activities (Amegbe et al., 2017), as well as cost implications in the waste disposal and material usage, are all enforcing demands for small and large firms to modify their behaviour. Top businesses nowadays consider simultaneously meeting customer and environmental needs, building green product platforms, reputation, and loyalty, as well as substantiating new values and innovations on the backdrop of environmental concerns of a paramount value to their success (Adawiyah, 2017). By embracing green marketing firms are positioned to additionally realise consequential benefits from an otherwise relatively cost-effective and temperate intervention (Joshia \& Rahman 2015). Additionally, in the endeavour to minimise environmental catastrophes, innovations or optimum energy utilisation can surface, as well as new products and market developments (Fuentesa, 2015).

\section{Green Marketing and Firm Performance}

Firm performance, also regarded as business performance is a prominent and vital concept in the broader business management research field which is often utilised in latent marketing and strategic management studies as a final dependent variable (Masocha, 2018). The concept' importance as an attribute in business is chiefly enshrined in determining the success or failure of strategies implemented by businesses (Amegbe, \& Hanu, 2016). Moreover, the significance of firm performance as the variable is enshrined in processes that pertain to planning and control processes in a firm (Mustafa et al., 2012). Scholars provide a relatively similar definition of firm performance but with differences existing in the manner in which firm performance is assessed in latent studies (Eneizan et al., 2016). Therefore, firm performance as a construct continues to undergo developments especially in the manner it is assessed due to challenges regarding the conceptual and methodological issues (Amegbe, \& Hanu, 2016; Masocha, 2018).

Two approaches are used in measuring firm performance namely, financial and nonfinancial measurement matrices (Eneizan \& Wahab, 2016). There has been a notable approach of predominantly utilising financial performance measures in the determination of firm performance amongst former academic works. Some of the classical financial accounting measurements (i.e. return on equity and return on sales) are deemed inadequate in ascertaining performance disparities amongst firms (Masocha, 2018). Likewise, there is a 
potential for ambiguous signals to emanate from classical financial accounting measures (e.g. return on investment and earnings per share) about incessant improvement and innovation (Eneizan \& Wahab, 2016). Similarly, the concept of firm performance in the marketing literature has classically been grounded on the premises of the profit maximisation principle from microeconomics (Amegbe \& Hanu, 2016). Reservations exist in the usage of financial measures in determining firm performance has because they have been to be backward-looking, rigid, and unsophisticated when ascertaining sustainability and green practices (Masocha, 2018). The integration of financial and nonfinancial measures is as such gaining momentum in contemporary studies emphasising the essence of non-financial matrices (i.e. customers, investors, and stakeholders) as well as processes, people development, and future (Eneizan \& Wahab, 2016). This is consistent with the view held by marketing and management theorists towards utilising a multidimensional approach by encapsulating the triple bottom line (TBL) elements of societal and environmental dimensions in measuring firm performance on top of financial performance (Eneizan \& Wahab 2016).

The study at hand adopts a similar approach to integrating financial and nonfinancial measures in the ascertainment of firm performance. Solely focusing on financial such as profit as well as other marketing aspects such as sales is irrelevant in the light of green concerns. Accordingly, firm performance is of significant apprehension for a firm being primarily driven by unique resources that are essential and can seldom be imitated (Eneizan \& Wahab, 2016). This suggests that there are embedded opportunities for firms that adopt green marketing to enhance their firm performance. The assimilation of green practices in business management processes has been propounded to have a bearing on the performance of firms (Hasan \& Ali,2015). Previous studies demonstrate that green marketing strategies resulted in firms improving their profitability through enhancing marketing performance and reducing costs (Durmaz, \& Yaşar, 2016). Financial and market performance are posited as accruals from green marketing for firms that go green (Punitha \& Mohd Rasdi 2013). However, scant empirical scholarships within the context of SMEs exist that assess a direct nexus between green practices and performance.

\section{Eco-Branding}

Eco-brand pertains to a contemporary approach towards the conventional branding tools such as name, signs, and design of products that posit no harm towards the environment (Rahbar \& Abdul Wahid, 2011). Eco-branding topographies provide a differentiation approach for firms vis-a-vis their non-green counterparts. A green brand presents substantial eco-advantages when contrasted with incumbents by appealing to customers who are prepared to prioritise going green (Grant, 2008),. Increasingly, branding strategies targeting both businesses to consumers (B-2-C) and business to business (B-2-B) markets are depending on being significantly green brands (Schmidt et al., 2017). Thus, marketing practitioners and researchers need to comprehend the extent to which brands sway consumer's buying decisions. Consistently, researchers and a practitioner in the field of marketing must comprehend the impact of eco-branding on consumer's buying decisions. A green brand identity is defined by explicit brand components as well as benefits connected to plummeting environmental harm (Lin et al., 2017). An appropriately executed green brand identity ought to afford paybacks to ecologically cognisant customers. Subsequently, the ultimate effect of brands on consumers buying decisions is reckoned as brand equity.

Environmental labels have a significant impact on the consumer's assessment regarding how brands perform environmentally. The concept of brand equity relates to the distinction in how a consumer responds towards a particular brand based on knowledge about the brand (Keller, 2014). Furthermore, brand knowledge encapsulates the entire connotations involving a brand with the customers e.g. opinions, 
emotions, metaphors, views, assertiveness, and experiences. Thus, green branding needs to prioritise the distinction of green products in contrast to non-green ones in terms of performance. For customers to consider altering their buying behaviour towards green products there is a need for a significant factor motivation driven by the existence of realistic emotional brand benefits underlying green products (Rahbar \& Abdul Wahid, 2011; Danciu, 2015). Green consumers are influenced by the existence of green values rather than products that have been repackaged without the necessary green values (Danciu, 2015). Empirical evidence established that green trust and green satisfaction are vital attributes that impact green brand preferences (Mourad \& Serag Eldin Ahmed 2012). Conversely, other studies have established that green branding strategies are faced with drawbacks with regards to consumers' understanding which tends to be incongruent to green performances by firms (Danciu, 2015). Thus, while genuinely green firms exist, these do not get to optimally reap rewards from their green efforts due to the prominent practise of greenwashing which dissuades customers from patronising genuinely green firms (Lin et al., 2017). Thus, hypothesis 1 proposes that there is a positive nexus between eco-branding and firm performance.

\section{Eco-Labelling}

Eco-labelling gained prominence within the context of marketing in 1992 following the promulgation of the Rio Earth Summit Agenda as a mechanism of advancing sustainable development (Muposhi, 2019). A green-label is regarded as a mark or emblem utilised on the container of green products, or insertion in an information sheet that complements the product, providing facts about the extent to which the products promote non-detrimental environmental effects (Struwig, \& Adendorff, 2018). Towards the latter part of the 1980s, various nations have implemented labelling systems on a national scale as a response to shifting consumer expectations towards purchasing greener products. As depicted by the labels, green marketing results in the eradication of information asymmetry with customers being furnished with information about the extent to which products meet the required environmental impact standards in production processes (Lamb et al., 2015). Germany's Blue Angel, the US's Green Seal, Japan's Eco-mark, Canada's Environmental Choice, European Commission's European Eco-label, and Scandinavian Nordic Swan are deemed as illustrations of national standards of eco-labels (Massari et al., 2016; Minkov et al., 2018). In South Africa, the South African Bureau of Standards (SABS) has an 'environment mark' which is operated concurrently with its classification of established and permitted standards (Tung, 2016).

There is a wide assortment of eco-labels with each type having attributes that are peculiar to the label strategy. Eco-labelling strategies can be identified based on affirmative, negative, or middle-of-the-road attributes (Hahnel et al., 2015). Positive labelling strategies confirm that labelled products positively contribute to the protection of the environment by containing at least one environmentally friendly attributes. Furthermore, negative labelling cautions consumers of the unsafe or unsafe components of the products. Finally, neutral labelling strategies focus on simply providing environmental information pertaining to the labelled product (Hahnel et al., 2015). Green-labelling is vital in differentiating green products and assisting customers in green purchasing (Struwig, \& Adendorff, 2018). Green labels have been utilised to furnish customers with meaning and functioned as a market-based mechanism envisioned to contribute towards environmental enhancements, with further advantages towards affirmative corporate brand image connotation for firms (Song et. al., 2019). Thus, greenlabels have been valuable towards creating environmental awareness and minimising information complexities associated with green products thereby enhancing consumer acceptance of green-product and their subsequent purchase (Song et al., 2019). Coherently, eco-labelling is a market-based economic mechanism that 
directs consumer's purchasing behaviour to consider product attributes besides the monetary aspect, thereby offering control to consumers who purchase green products.

Existing empirical studies pertaining to eco-labels have indicated that green labels influence firm performance in the automobile industry (Kushwaha \& Sharma, 2015), wine industry (Leenders \& Chandra, 2013) their understanding, meaning, and perceptions on these labels. Eco-labels are used as tools by consumers to facilitate decision making in selecting environmentally-friendly products and enabling customers to know how products are made. This study focused on investigating greenlabels in the context of SMEs due to inadequate research efforts in the field and postulated in hypothesis 2 that there is a positive nexus between eco-labelling and firm performance.

\section{Environmental Advertisements}

Environmental advertising also known as green advertising finds its prominence out of the growing expectations on the part of businesses to reach environmentally concerned customers with the necessary green information of their products and services (Wahba, 2012). Environmental (or green) advertisements convey messages that comprise ecological, environmental sustainability, or eco $\square$ friendly requirements and expectations of the ecologically conscious interested party (Leonidou et al., 2011). Furthermore, environmental advertising focuses on how products or services are related to the natural environment, support an environmentally conscious lifestyle, and reflect a corporate environmental appearance or concern (Schmuck et al., 2018). Analogous to rising global green activities and the public consideration towards environmental complications, most firms have opted for environmental advertisements. In this regard, the various media are being utilised, inter alia, social media, newspapers, radios, billboards, magazines through the utilisation of primarily three strategies, namely, functional fact-based appeals, image-based emotion appeals, or any of the two (Schumack et al.,
2018). Firstly, functional fact-based appeals are green adverts that that are premised on highlighting particular utilitarian features of green products in contrast to rivalry traditional products (Matthes et al., 2014). Secondly, the image-based emotional appeal focuses on transferring the environmental emotional positioning and the related affective responses towards a brand (Schumack et al., 2018). The executional style in this kind of advertising is through the utilisation of pleasant nature scenic images which are aimed at evoking affirmative affective responses (Hartmann et al., 2013; Parguel et al., 2015). Finally, a combination (functional and emotional appeals) positioning strategy has been deemed to attain optimum effects towards changing consumer attitudes (Schumack et al., 2018).

The primary aim of the green advertisement is to inspire consumers' purchase activities towards products that ensure no or less harm to the environment thereby and redirecting their alertness of the progressive contribution of their purchase behaviour (Rahbar \& Abdul Wahid, 2011). However, the phenomenon of greenwashing is also a prevalent force negatively affecting the attitude of consumers towards green advertising (Lin et al., 2017). As businesses pursue environmentally cognisant buyers, their environmental claims within their advertisements are subjected to severe scrutiny (Leonidou et al., 2011; Schumack et al., 2018). Green advertising campaigns by small and large businesses need to be effective in enabling consumers to exercise their quest for social backing or outward personal expression (Lin et al., 2017).

To remain competitive, businesses are continuously responding by becoming environmentally conscious thereby environmental advertising has become a major part of marketing. Numerous studies have revealed that consumers are increasingly interested in the green content about advertisements and they have increasingly influenced by-products they deem to be supporting the environment (Leonidou et al., 
2011). More precisely, the relationship between the adoption of environmental advertisements and firm performance has been confirmed in the automobile industry (Kushwaha \& Sharma, 2015). In the context of SMEs, a global outlook study established that green marketing strategies (environmental advertising included) contribute towards the financial performance of SMEs (Miroshnychenko et al., 2017). However, studies that focus on the South African SMEs are scant, as such; hypothesis 3 proposed that there is a positive nexus between environmental advertising and firm performance.

\section{Research Design and Methodology}

The quantitative research methodology was utilised in this study and the cross-sectional survey research design was applied. The population of the SMEs in the Limpopo Province comprises the sample frame for this study. According to Small Enterprises Development Agency (Seda, 2018), there are approximately 314880 of both registered and unregistered SMEs found in various sectors in the Limpopo Province. As such, obtaining a complete sample listing of all SMEs in the province with the greater portion being in the informal sector was a daunting task for this study. Consequently, for this study, the non-probability sampling method was used, and convenience sampling was then followed in choosing participants to get data from. The sample size was 156 respondents who were either owners or managers in the SME businesses that were investigated. Furthermore, the study made use of a survey in a form of paperbased self-assessment questionnaires where the respondents answer the questions at their own time. In this study, quantitative data was used. The survey was operationalised through printed questionnaires which were distributed inperson and electronically (e-mail). The research instrument was designed based on a critical literature review and comprised of a 5-point Likert scale format of questionnaire items.

The data analysis stage followed the usual two-pronged approach, namely, descriptive and inferential analysis. IBM Statistical
Software for Social Sciences Statistical software and Analysis of Moment Structures (AMOS Version 25.0) were used in performing statistical analysis. Inferential analysis in this study primarily constituted the performance of structural equation modelling (SEM) which constitutes the computation of the multiple regression analysis of the postulated hypotheses. SEM constitutes two components, namely, the measurement model and the structural model. The measurement model is equated to factor analysis and focuses on determining the best fit between the factors being measured and the items used to measure the items thereof.

The measurement model enables the researcher to model or establish relationships that exist among indicators of observed variables and their related latent variables (unobserved variables or constructs) through the definition of a structural model (MartínezLópez et al., 2013). Together with the statistics from the measurement model, the structural model enables the researcher to accept or reject the hypotheses (Mishra, 2015). The structural model explains the relationship between latent variables by the way of determining the variance explained and unexplained. Thus, this becomes similar to the analysis of the relationships in the regression models. The structural model is built on various estimation models, and usually, it depends on the software that is utilised (Mishra, 2015). Of the various estimation models that exist, such as, Maximum Likelihood (ML) is the commonly used approach and was utilised in this study because it is highly consistent with categorical data within a multivariate normality context (Dandagi et al., 2016).

\section{Results and Discussion}

\section{Descriptive Analysis}

The data presented in this section was gathered using questionnaires from a sample of 181 respondents. The questionnaires that were returned are 156 and that produces an $86 \%$ response rate which is deemed ideal to proceed with the data analysis. The following discussion 
presents the biographic information on the sample participants as depicted in Figure 1.

As in the figure above, $58 \%$ were male and $42 \%$ were female in terms of gender distribution. In terms of age, most $(52 \%)$ of the respondents were between the 31 to 40 years age group. As for education, the majority (43\%) of the respondents had a matric qualification with the next category being those with diplomas having 30\%. The respondents also indicated the different types of legal ownership between sole proprietorship, partnerships, co-operatives (Coops), close cooperation (CCs), and companies, and the percentages were $15 \%, 40 \%, 19 \%, 26 \%$, and $16 \%$ respectively. In terms of the different industries, there were manufacturing (37\%), wholesaling and retailing (24\%), agriculture $(31 \%)$, services $(7 \%)$ and there was none from mining and tourism. Of the sampled firms, employees were $5 \%$ less than 5 employees, $45 \%$ between 6 and $10,28 \%$ were between 11 to $20,13 \%$ were between 21 to $30,8 \%$ had 31 to 40 workers, only $1 \%$ had between 41 to 50 employees and no firm had above 50 employees. The display descriptive statistics of the main variables that were utilised to investigate the stated hypotheses.

\section{Inferential Analysis}

This study primarily utilised the structural equation modelling (SEM) as the inferential analysis procedure. However, before SEM can be conducted, factor analysis needs to be and was conducted in this study. Maiden tests, namely, screening for missing data, outliers, and normality (kurtosis and skewness) indicated no substantial irregularities towards the use of SEM. Table 2 presents information on normality tests. Additionally, exploratory factor analysis (EFA) on the premises principal component analysis (PCA) and varimax rotation was applied to ascertain the dimensionality of the study variables. The Varimax rotation, an orthogonal rotation option was applied in this study. Preference for varimax was informed by its ability to simultaneously minimise the number of variables that has high loadings for each particular factor and ensuring that insignificant loadings are even more decreased (Yong \& Pearce, 2013)

Prior to performing EFA, data was first measured for sample adequacy at the hand of Kaiser-Meyer-Olkin (KMO) and Bartlett's Test of Sphericity (BTS) measures, of which all the variables had KMO statistics greater than 0.5 and BTS was significant $(\mathrm{p}<.05)$ entailing appropriateness of data for factor analysis (Cooper \& Schindler, 2008) (See Table 3). EFA results on standardised factor loadings (SFLS) are presented in Table 3 with all questionnaire items utilised in the analysis displaying substantially high loadings beyond the threshold of 0.50 (Tabachnick \& Fidell, 2007). However, four items (Econbra4, Econbra5, Envadv4, Envadv5) were dropped because of crossloadings, as such out of the initial 18 items 14 were later used for further assessments.

\section{Measurement Model}

Convergence validity was ascertained through Cronbach's coefficient alpha $(\alpha)$ tests with all the values being bigger than the recommended

Table 1: Respondents' biographical information

\begin{tabular}{ll}
\hline \multicolumn{1}{c}{ Variable } & \multicolumn{1}{c}{ Frequency } \\
\hline Gender & Male $(58 \%)$, Female $(42 \%) 0.489$ \\
\hline Age in years & Below $21(3,5 \%), 21-30(20.9 \%), 31-40(52,3 \%), 41-50(15.1 \%)$, Above $50(8.1 \%)$ \\
\hline Education & Undergraduate $(19.8 \%)$, Post graduate $(7 \%)$, Matric (43\%), Diplomas (30.2\%) \\
\hline Business type & Proprietorship (15\%), Partnerships (40\%), Co-ops (19\%), CCs (26\%), Company $(16 \%)$ \\
\hline Industry & Manufacturing (37\%), Wholesaling and Retailing (24\%), Agriculture (31\%), Services $(7 \%)$ \\
\hline Employees & less than 5 (5\%), 6-10 (45\%), 11-20(28\%), 21-30(13\%), 31- 40(8\%), 41-50 (1\%) \\
\hline
\end{tabular}


Table 2: Descriptive statistics

\begin{tabular}{lcccccccc}
\hline Variable & Mean & StDev & Variance & Min & Max & Mode & Skewness & Kurtosis \\
\hline Ecolab1 & 4,4419 & 0,6251 & 0,3907 & 1,0000 & 5,0000 & 4 & 1,05 & 0,97 \\
Ecolab2 & 4,5581 & 0,5225 & 0,2731 & 3,0000 & 5,0000 & 5 & $-0,49$ & $-1,22$ \\
Ecolab3 & 4,6512 & 0,5481 & 0,3004 & 2,0000 & 5,0000 & 5 & $-1,13$ & 0,60 \\
Ecolab4 & 4,6395 & 0,4830 & 0,2332 & 4,0000 & 5,0000 & 5 & $-0,59$ & $-0,69$ \\
& & & & & & & & \\
Ecobra1 & 4,2674 & 0,5407 & 0,2923 & 3,0000 & 5,0000 & 4 & 0,11 & $-0,39$ \\
Ecobra2 & 4,3488 & 0,6091 & 0,3710 & 1,0000 & 5,0000 & 4 & $-1,23$ & 1,04 \\
Ecobra3 & 4,3721 & 0,5749 & 0,3305 & 2,0000 & 5,0000 & 4 & $-0,62$ & 1,24 \\
Ecobra4 & 4,4302 & 0,5211 & 0,2715 & 3,0000 & 5,0000 & 4 & 0,03 & $-1,03$ \\
Econbra5 & 4,3023 & 0,5955 & 0,3546 & 1,0000 & 5,0000 & 4 & $-1,18$ & 1,17 \\
Envadv1 & 4,5349 & 0,5246 & 0,2752 & 3,0000 & 5,0000 & 5 & $-0,39$ & $-1,10$ \\
Envadv2 & 4,6047 & 0,5152 & 0,2654 & 3,0000 & 5,0000 & 5 & $-0,70$ & $-0,92$ \\
Envadv3 & 4,7093 & 0,4567 & 0,2086 & 4,0000 & 5,0000 & 5 & $-0,94$ & $-1,15$ \\
Envadv4 & 4,4070 & 0,5397 & 0,2912 & 3,0000 & 5,0000 & 4 & $-0,08$ & $-1,07$ \\
Envadv5 & 4,4070 & 0,5816 & 0,3383 & 3,0000 & 5,0000 & 4 & $-0,36$ & $-0,72$ \\
Firmper1 & 4,3953 & 0,5375 & 0,2889 & 3,0000 & 5,0000 & 4 & $-0,03$ & $-1,06$ \\
Firmper2 & 4,4070 & 0,5174 & 0,2677 & 3,0000 & 5,0000 & 4 & 0,12 & $-1,20$ \\
Firmper3 & 4,4070 & 0,5397 & 0,2912 & 3,0000 & 5,0000 & 4 & $-0,08$ & $-1,07$ \\
Firmper4 & 4,4070 & 0,5816 & 0,3383 & 3,0000 & 5,0000 & 4 & $-0,36$ & $-0,72$ \\
\hline
\end{tabular}

Table 3: Sample adequacy

\begin{tabular}{llccccc}
\hline \multicolumn{1}{c}{ Measures } & MEAN & SD & EIGEN & TVE (\%) & KMO & BTS \\
\hline ECOLAB & 4.58 & 1.942 & 4.158 & 83.157 & 0.806 & 0.000 \\
\hline ECOBRA & 4.32 & 1.716 & 2.765 & 55.103 & 0.773 & 0.000 \\
\hline ENVADV & 4.64 & 1.290 & 2.267 & 56.486 & 0.576 & 0.000 \\
\hline FIRMPER & 4.42 & 1.870 & 3.499 & 87.474 & 0.757 & 0.000
\end{tabular}

0.7 demonstrating substantial convergence of the data. Table 4 illustrates Cronbach's coefficient values that are between 0.759 and 0.951 which specify the reliability of the data. Composite Reliability (CR) and Average Variance Extracted (AVE) were applied in determining internal consistency about the constructs. CR and AVE define the magnitude of variance about a construct's measure contrasted to the measurement error (Fornell
\& Lacker, 1981). Parameter assessments and related $t$-values for each construct are used in the calculation of values for CR and AVE were used (Fornell \& Lacker, 1981). For satisfactory internal consistency $\mathrm{CR}$ values $>0.7$ and AVE values $>0.5$ are needed (Hair et al., 2014). Entirely, as exposed in Table 4, the CR and AVE measurements surpassed the proposed cut-off standards, thus describing the internal steadiness of the constructs. 
Table 4: Measurement model

\begin{tabular}{|c|c|c|c|c|c|c|c|}
\hline Factor & Items & SFLS & $\begin{array}{l}\text { Cronbach's } \\
\text { Alpha if Item } \\
\text { Deleted }\end{array}$ & Cronbach's $\alpha$ & AVE & CR & R-Squared \\
\hline \multirow[t]{4}{*}{$\begin{array}{l}\text { Eco-labelling } \\
\text { (ECOLAB) }\end{array}$} & Ecolab1 & .813 & $\begin{array}{l}.834 \\
.829 \\
.833 \\
.834 \\
.830\end{array}$ & 0.907 & 0.712 & 0.916 & --- \\
\hline & Ecolab2 & .867 & .829 & & & & \\
\hline & Ecolab3 & .905 & .833 & & & & \\
\hline & Ecolab4 & .826 & .834 & & & & \\
\hline \multirow{3}{*}{$\begin{array}{l}\text { Eco-branding } \\
\text { (ECOBRA) }\end{array}$} & Ecobral & .811 & .838 & 0.759 & 0.733 & 0.892 & --- \\
\hline & Ecobra2 & .870 & .852 & & & & \\
\hline & Ecobra3 & .886 & .841 & & & & \\
\hline \multirow{3}{*}{$\begin{array}{c}\text { Environmental } \\
\text { Advertising } \\
\text { (ENVADV) }\end{array}$} & Envadv1 & .818 & .840 & 0.833 & 0.733 & 0.856 & --- \\
\hline & Envadv2 & .946 & .841 & & & & \\
\hline & Envadv3 & .796 & .842 & & & & \\
\hline \multirow{4}{*}{$\begin{array}{c}\text { Firm } \\
\text { Performance } \\
\text { (FIRMPER) }\end{array}$} & Firmper1 & .936 & .830 & 0.951 & 0.871 & 0.964 & 0.94 \\
\hline & Firmper2 & .948 & .829 & & & & \\
\hline & Firmper3 & .954 & .832 & & & & \\
\hline & Firmper4 & .894 & .831 & & & & \\
\hline
\end{tabular}

Furthermore, discriminant validity was ascertained through correlation analysis. Herein, discriminant validity sought to determine whether constructs that were meant to be unrelated were indeed so. The rule of thumb is that the inter-construct correlation coefficients (r) should not exceed 0.80 (Mishra, 2015). The correlation analysis (Table 5) indicates that a positive and significant relationship $(r=0.465$; $\mathrm{p}=<0.001$ ) existed between eco-branding and eco-labelling. A positive relationship though insignificant $(r=0.017 ; \mathrm{p}=0.879)$ was found between eco-labelling and environmental advertising. However, between eco-branding and environmental advertising a negative and insignificant relationship $(r=-0.067 ; \mathrm{p}=0.542)$ was found. Finally, there was a negative insignificant between firm performance and Eco labelling $(r=-0.103 ; \mathrm{p}=0.348)$ together with ecobranding $(r=-0.168 ; \mathrm{p}=0.122)$. Whereas, there was a significant positive correlation between firm performance and environmental advertising at $r=0.743$ and $p=<0.001$. Conclusively, discriminant validity transpired in the study as no $r$ value was above 0.80 . 
Table 5: Pearson correlation analysis

\begin{tabular}{lcccc}
\hline & ECOLAB & ECOBRA & ENVADV & FIRMPER \\
\hline ECOLAB & 1 & & & \\
ECOBRA & $0,46(0,000)$ & 1 & & \\
ENVADV & $0,017(0,879)$ & $-0,067(0,542)$ & 1 & \\
FIRMPER & $-0,103(0,348)$ & $-0,168(0,122)$ & $0,743(0,000)$ & 1 \\
\hline
\end{tabular}

ECO-LABELLING ECO-BRANDING ENVIRONADVERT FIRM PERFORMANCE

\section{Structural Equation Modelling}

The section pertains to the research hypotheses and presents the conclusions on the tested hypotheses. The next table (Table 6) presents the standardised regression weights $(\beta)$ for the path diagram about the hypothesised variables through a path analysis approach in structural equation modeling (SEM). Through AMOS version 25, the SEM approach was applied because of the inherent advantages of simultaneously estimating parameters in one model. In ascertaining model fitness, the $\mathrm{R}$-squared $\left(\mathrm{R}^{2}\right)$ value relating to the endogenous latent variable, namely, firm performance ( $94 \%$ ) indicates the extent of predictive ability of the model (see figure 1).
Figure 1 diagrammatically portrays the structural model with the results of the path analysis presented in Table 6 below. To test the hypotheses, standardised regression weights were computed and the guiding rule was if the $\mathrm{p}$-value is less than 0.05 the null hypothesis is rejected in support of the alternative hypothesis. For the first hypothesis (H1) which stated that there is a positive and significant relationship between eco-labelling and firm performance, the null hypothesis was also rejected. As indicated in Table 6 below, at $\beta=0.203, t=5.007$, and $\mathrm{P}<0.001$ the null hypothesis is rejected. Also, for the second hypothesis (H2) which stated that a positive and significant relationship existed between eco-branding and firm performance the null hypothesis was rejected. According to Table 6 below, at $\beta=0.705, \mathrm{t}=17.618$, and $\mathrm{P}<0.001$,

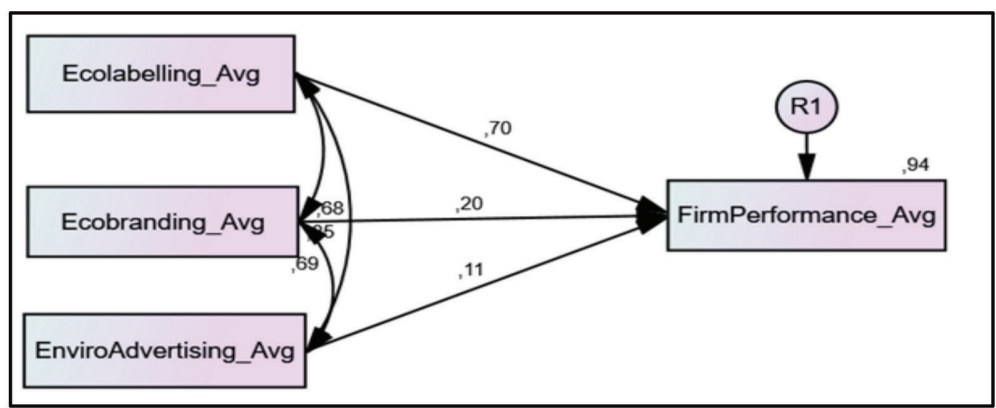

Figure 1: Path diagram with structural model

Table 6: Structural model

\begin{tabular}{|c|c|c|c|c|c|c|c|}
\hline \multicolumn{3}{|c|}{ Hypothesised relationships } & $\beta$ & S.E. & C.R. & $\mathbf{P}$ & Decision \\
\hline Eco-labelling & $\rightarrow$ & Firm Performance & 0,705 &, 038 & 17,618 & $* * *$ & Supported \\
\hline Eco-branding & $\rightarrow$ & Firm Performance & 0,203 &, 037 & 5,007 & $* * *$ & Supported \\
\hline Enviro-Advertising & $\rightarrow$ & Firm Performance & 0,114 &, 045 & 3,969 & $* * *$ & Supported \\
\hline
\end{tabular}


$\mathrm{H} 2$ is supported. Lastly, regarding the third hypothesis (H3) which posited the existence of a positive and significant relationship between environmental advertising and firm performance, thus, the alternative hypothesis was affirmed. As outlined in Table 6 below, at $\beta=0.114, \mathrm{t}=3.969$, and $\mathrm{P}<0.001, \mathrm{H} 3$ is supported.

Firstly, the results about the hypothesised relationship between eco-labelling and firm performance which was found to be positive and significant this entails directly and significantly entails that eco-labelling influences the purchasing decisions by customers. This finding purports that SME operators and their owners acknowledge the role that is played by environmental and social information on the packaging materials in determining the competitiveness of their strategies. With more consumers being informed and conscious about environmental issues, developing eco-labelling strategies is proving essential and SMEs can seize the opportunities provided in eco-labelling in contrast to large organisations.

Secondly, the tentative relationship between green branding and firm performance was also found to be positive. For SMEs this entails that branding strategies that promise success in the contemporary environments have to considerably encapsulate green philosophies. This further implies a significant change in the environments and with demands being conspicuous that green features and characteristics of a brand are a differentiating standard between successful and less successful firms. Lastly, SEM results of a postulated positive relationship between environmental advertising and firm performance were also affirmative. Accordingly, the extent of advertising activities that are inclined and embedded with green concerns a firm undertakes the more success it achieves pertaining to its firm performance measures.

\section{Conclusions and Recommendations}

Environmental concerns are predominantly steering and determining corporate cultures in the business milieus and this phenomenon is being noted by consumers as well as other stakeholders. Conspicuously, more and more SMEs are adopting green marketing tools across the world as well as in South Africa. Therefore, this study focused on whether or not green marketing tools utilised by SMEs influence their performance. This section presents the conclusions on the research hypotheses based on the findings of the study. Overall, the findings established that there is a significant and positive nexus in all the tested hypotheses. This implies that eco-labelling, green branding, and environmental advertising positively influence firm performance amongst SMEs concerning South Africa.

With affirmations of escalating environmental degradation apprehensions, the findings consistently indicate that successful SMEs are based on eco-branding, eco-labels, and environmental advertising. Imperatively, the establishment of positive and significant nexuses pertaining to the hypothesised relationship between entails that the more SMEs involved eco-labelling, green branding, and eco-advertising the more they should expect their overall firm performance to increase. This implies that contemporary customers are regarding green marketing as a paramount aspect to their patronising of firms. The demand for firms to drift away from non-environmental is growing. Thus, the use of environmental awareness, environmental training, and inclusion of environmental messages has a significant impact on the performance of small firms. This result is found to be consistent with findings in other studies which concluded that the extent to which a firm is involved in green marketing practices has a positive and significant relationship with its economic performance (Fraj-Andrés et al. 2013; Wanjohi et al., 2013; Kumar et al., 2015).

The study established that the majority of SMEs would do well if they were to implement green marketing in their business as a strategy. On that backdrop, the researcher recommends that SMEs should consider enshrining green marketing practices in their decision-making 
and strategies to enhance their position. Furthermore, with the competitive terrain being amplified in the contemporary environments, SMEs' managers need to consider the essence of eco-labelling, eco-branding, and environmental advertising in their marketing strategies to enhance their competitiveness against large firms. Undoubtedly, green marketing is a strategy that is going to be around for some time in the business world. Thus, an elaborate and comprehensive sustainable and green approach should be pursued by SMEs that desire to optimise their performance. This implies that at every contact point with customers the green elements of their branding should be clear and obvious to the customers and stakeholders. Eco-labelling, eco-branding, and environmental advertising are important tools to communicate green efforts on behalf of SMEs. There is no need for uncertainty on what SMEs represent within the context of green marketing as large firms are seriously considering going green. Similarly, any firm that chooses to ignore the implications underpinning green marketing tools is likely to find it hard in the contemporary business world. The time when the price and value were the most important factors that moved a customer to a product is drifting away.

The study recommends further research to be directed towards understanding the subvariables that underlie green marketing so to ensure that SMEs can pursue the strategy with clarity. To enhance the diffusion of green marketing amongst firms within the value chain, there is a need for firms to further contribute towards green advances by encouraging their suppliers to behave in a more environmentally responsible way (Belz \& Peattie, 2010). Herein, the ethics and philosophies of a firm have become an integral part of marketing and business in the face of greenwashing (Durmaz \& Yaşar, 2016). Thus, there is more research that needs to be done about the concept of greenwashing within the context of SMEs. Furthermore, research needs to be conducted on the multidimensionality of firm performance and how green marketing practices influence firm performance in that regard. Future studies can also explore the antecedents to green marketing practices within the context of SMEs. For policymakers, there is a need to ensure a framework on the utilisation of eco-branding, green advertising, and ecolabelling is developed that is customised for SMEs. Consequently, this study goes a long way in providing a background for this framework. However, the major limitations of this study rest in the focus area. The study focused on SMEs in general, and in one province of South Africa. A nationwide study could be more enriching as results may differ from province to province.

\section{Acknowledgements}

The researcher wants to acknowledge Nyasha Chiuta for assisting with proofreading the draft of the manuscript. Acknowledgements are also extended to the University of Limpopo for funding the publication costs of the article

\section{References}

Adawiyah, W. R. (2017). Determinants Of green Marketing quality practices among Small Medium Enterprises (SMEs). Ekuitas (Jurnal Ekonomi Dan Keuangan), 1(2), 240-258.

Amegbe, H., \& Hanu, C. (2016). Exploring the relationship between green orientation, customer-based Brand equity (CBBE) and the competitive performance of SMEs in Ghana. Journal of Marketing Development and Competitiveness, 10(1), 80-93.

Amegbe, H., Owino, J. O., \& Nuwasiima, A. (2017). Green Marketing Orientation (GMO) and Performance of SMEs in Ghana. American Journal of Management, 11(1), 99-109.

Carvalho, F., Domingues, P., \& Sampaio, P. (2019). Communication of commitment towards sustainable development of certified Portuguese organisations: Quality, environment and occupational health and safety. International Journal of Quality \& Reliability Management, 36(4), 458-484. 
Chen, H., Bernard, S., \& Rahman, I. (2019). Greenwashing in hotels: A structural model of trust and behavioural intentions. Journal of Cleaner Production 206, 326-335.

Cooper, D. R., \& Schindler. P. (2008). Business Research Methods, (10th ed.). New York, USA: Mcgraw-Hill.

Danciu, V. (2015). Successful Green Branding, a New Shift in Brand Strategy: Why and how it works. The Romanian Economic Journal, 56, 47-64.

Dandagi, S., Bhushi, U., Bagodi, V., \& Sinha, D. (2016). Strategic management of technical university: structural equation modelling approach. Journal of Modelling in Management, 11(1), 75-90.

Durmaz, Y., \& Yaşar, H. V. (2016). Green Marketing and Benefits to Business. Business and Management Studies, 2(2), 64-71.

Emery, B. (2012). Sustainable Marketing. England: Pearson

Eneizan, B. M., \& Wahab, K. A. (2016). Effects of Green Marketing Strategy on the Financial and Non-Financial Performance of Firms: A Conceptual Paper. Arabian Journal of Business and Management Review, 6(5), 1-7.

Eneizan, B. M., Wahab, K. A., Zainon M. S., \& Obaid, T.F. (2016). Effects of Green Marketing Strategy on the Financial and Non-Financial Performance of Firms: A Conceptual Paper. Arabian Journal of Business and Management Review (Oman Chapter), 5(12), 14-27.

Ferreira, J. \& Fernandes, C. (2017). Resources and capabilities' effects on firm performance: what are they?", Journal of Knowledge Management, 21(5), 1202-121.

Fornell, C. D., \& Lacker, D. F. (1981). Evaluating structural equation models with unobservable variables and measurement error. Journal of Marketing Research, 18, 39-50.
Fowler, S. J. \& Hope, C. (2007). Incorporating Sustainable Business Practices into company Strategy. Business Strategy and the Environment, 16, 26-38.

Fraj-Andrés, E., Martinez-Salinas, E., \& MatuteVallejo, J. (2009). Journal of Business Ethics, 88, 263.

Fuentesa, C. (2015). How green marketing works: Practices, materialities, and images. Scandinavian Journal of Management, 31(2), 192-205.

Govender, J. P., \& Govender, T. L. (2016). The influence of green marketing on consumer purchase behavior. Environmental Economics, 7(2), 77-85.

Guckian, M., De Young, R., \& Harbo, S. (2017). Beyond Green Consumerism: Uncovering the Motivations of Green Citizenship. Michigan Journal of Sustainability, 5(1), 73-94.

Hahnel, U. J., Arnold, O., Waschto, M., Korcaj, L., Hillmann, K., Roser, D., \& Spada, H. (2015). The power of putting a label on it: green labels weigh heavier than contradicting product information for consumers' purchase decisions and postpurchase behavior. Frontiers in psychology, 6, 1392 .

Hair, J., Hult, T., Ringle, C., \& Sarstedt, M. (2014). A Primer on Partial Least Squares Structural Equation Modeling (PLSSEM). CA, USA: Sage Publications, Inc. (Thousand Oaks).

Hamann, R., Smith, J., Tashman, P., \& Marshall, R. S. (2017). Why Do SMEs Go Green? An Analysis of Wine Firms in South Africa. Business \& Society, 56(1), 23-56.

Handayani, W., \& Prayogo, R. A. (2017). Green Consumerism :an Eco-Friendly Behaviour Form Through The Green Product Consumption and Green Marketing. SINERGI, 7(2), 25-29.

Hari Adi, P., \& Adawiyah, W. (2018), The impact of religiosity, environmental marketing orientation and practices on performance. 
Journal of Islamic Marketing, 9(4), 841862.

Hart, S. (1995). A Natural-Resource-Based View of the Firm. The Academy of Management Review, 20(4), 986-1014.

Hartmann, P., Apaolaza, V., \& Alija, P. (2013). Nature imagery in advertising: Attention restoration and memory effects. International Journal of Advertising, 32(2), 183-210.

Hasan, Z., \& Ali, N. A. (2015). The impact of green marketing strategy on the firm's performance in Malaysia. Procedia - Social and Behavioral Sciences 172, 463-470.

Joshia, Y., \& Rahman, Z. (2015). Factors Affecting Green Purchase Behaviour and Future Research Directions. International Strategic Management Review, 3(1-2), 128143.

Kanonuhwa, M, \& Chimucheka, T. (2014). Green Marketing and Purchase Behaviour of Generation Y-Consumers. Mediterranean Journal of Social Sciences, 5(20), 27852788.

Keller, K. L. (2014). Consumer brand relationships. Journal of Brand Management, 21(5), 365-365.

Kumar, M., Townsend, J. D., \& Vorhies, D. W. (2015). Enhancing Consumers' Affection for a Brand Using Product Design. Journal of Product Development \& Management, 32(5), 716-730.

Kushwaha, G. S., \& Sharma, N. K. (2015). Green initiatives: a step towards sustainable development and firm's performance in the automobile industry. Journal of Cleaner Production, 121, 116-129.

Lamb, C.W., Hair, J. F. (Jr), McDaniel, C., Boshoff, C., Terblanche, N., Elliott, R., \& Klopper, H.B. (2015). Marketing. Oxford University Press: Cape Town, South Africa.

Leenders, M., \& Chandra, Y. (2013). Antecedents and consequences of green innovation in the wine industry: the role of channel structure. Technology Analysis and Strategic Management 25(2), 203-218.

Lekhanya, L. M. (2014). The Level of awareness of green marketing and its managerial implications amongst selected South African manufacturing Small, Medium and Micro Enterprises (SMMEs) in KwaZulu-Natal. Journal of Economics and Behavioral Studies, 6(8), 625-635.

Leonidou, L., Leonidou, C., Palihawadana, D., \& Hultman, M. (2011). Evaluating the green advertising practices of international firms: a trend analysis. International Marketing Review, 28(1), 6-33.

Lin, J., Lobo, A., \& Leckie, C. (2017). Green brand benefits and their influence on brand loyalty. Marketing Intelligence \& Planning, 35(3), 425-440.

Mahapatra, S. (2013). A study on consumer's perception for green products: An empirical study from India. International Journal of Management \& Information Technology, 7(1), 924-933.

Martínez-López, F. J., Gázquez-Abad, J. C., \& Sousa, C. M. P. (2013). Structural equation modelling in marketing and business research: Critical issues and practical recommendations. European Journal of Marketing, 47(1/2), 115-152.

Masocha, R (2018). Delineating Small Businesses' Firm Performance from a Contemporary Sustainable Development Approach in South Africa. Acta Universitatis Danubius. Economica, 14(7), 192-206.

Masocha, R., \& Fatoki, O. (2018). The role of mimicry isomorphism in sustainable development operationalisation by SMEs in South Africa. Sustainability, 10(4), 1-16.

Massari, S., Sonnemann, G., \& Balkau, F. (2016). Life Cycle Approaches to Sustainable Regional Development, Routledge: New York, USA.

Matthes, J., Wonneberger, A., \& Schmuck, D. (2014). Consumers' green involvement 
and the persuasive effects of emotional versus functional ads. Journal of Business Research, 67(9), 1885-1893

McDougall, N., Wagner, B., \& MacBryde, J. (2019). An empirical explanation of the natural-resource-based view of the firm. Production Planning and Control, 30(16), 1366-1382

Medhi, M. (2015). A Study on the Green Marketing Practices Adopted by Various Companies in India. International Journal of Marketing and Human Resource Management (IJMHRM), 6(3), 83-88.

Minkov, N., Bach, V., \& Finkbeiner, M. (2018). Characterization of the Cradle to Cradle Certified $^{\mathrm{TM}}$ Products Program in the Context of Eco-labels and Environmental Declarations. Sustainability 10(3), 738.

Miroshnychenko, I., Barontini R., \& Testa, F. (2017). Green practices and financial performance: A global outlook. Journal of Cleaner Production, 147, 340-351.

Mishra, P. (2015). Business Research Methods. New Dehli, India: Oxford University Press.

Mourad, M., \& Serag Eldin Ahmed, Y. (2012). Perception of green brand in an emerging innovative market. European Journal of Innovation Management, 15(4), 514-537.

Muposhi, A. (2019). Emergence of Green Marketing Capitalism in South Africa: Implications for Green Economy Agenda. International Journal of Business and Management Studies, 11(1), 1-15.

Mustafa S. A., Othman A. R., \& Perumal, S. (2012). Corporate social responsibility and company performance in the malaysian context. Procedia-Social and Behavioral Sciences, 65, 897-905.

Negassa, G. J. (2015). The effects of business ethics on consumers' perceptions of merchandizing and service giving businesses in Mekelle, Ethiopia. International Journal of Scientific and Research Publications, 5(2), 1-7.
Ottman, J. A. (2011).The new rules of green marketing: strategies, tools, and inspiration for sustainable branding. San Francisco, CA: Berrett-Koehler Pub.

Parguel, B., Benoit-Moreau, F., \& Russell, C. A. (2015). Can evoking nature in advertising mislead consumers? The power of 'executional greenwashing. International Journal of Advertising, 34(1), 107-134.

Peattie, K., \& Belz, F. (2010). Sustainability marketing - An innovative conception of marketing. Marketing Review St Gallen, 27(5), 8-15.

Peattie, K., \& Crane, A. (2005). Green marketing: legend, myth, farces or prophesies? Qualitative Market Research. An International Journal, 8(4), 357-370.

Punitha, S., \& Mohd, R. (2013). Corporate Social Responsibility: Adoption of Green Marketing by Hotel Industry. Asian Social Science, 9(17), 79-93.

Rahbar, E., \& Abdul Wahid, N. (2011). Investigation of green marketing tools' effect on consumers' purchase behaviour. Business Strategy Series, 12(2), 73-83.

Ramon-Jeronimo, J. M., Florez-Lopez, R. \& Araujo-Pinzon, P. (2019). Resource-Based View and SMEs Performance Exporting through Foreign Intermediaries: The Mediating Effect of Management Controls. Sustainability, 11, 3241.

Rungani, E. C., \& Potgieter, M. (2018). The impact of financial support on the success of small, medium and micro enterprises in the Eastern Cape province. Acta Commercii, 18(1), a591.

Schmidt, S., Langner, S., Hennigs, N., Wiedmann, K., Karampournioti, E., Lischka, G., \& Briesemeister, B. (2017). The green brand: Explicit and implicit framing effects of ecolabelling on brand knowledge. Cogent Psychology, 4,1.

Schmuck, D., Matthes, J., Naderer B., \& Beaufort, M. (2018). The Effects of Environmental Brand Attributes and 
Nature Imagery in Green Advertising. Environmental Communication, 12(3), 414429.

SEDA (2018). SMME Quarterly Update 1st Quarter 2018. http://www.seda.org.za/ Publications/Publications/SMME\%20 Quarterly\%202018-Q1.pdf [accessed: 30/ 07/2019].

Simãoa, L., \& Lisboa, A. (2017). Green Marketing and Green Brand - The Toyota Case. Procedia Manufacturing, 12, 183194.

Song, Y., Qin, Z., \& Yuan, Q. (2019). The Impact of Eco-Label on the Young Chinese Generation: The Mediation Role of Environmental Awareness and Product Attributes in Green Purchase. Sustainability, 11(4), 973.

Sreen, N., Purbey, S., \& Sadarangani, P. (2018). Impact of culture, behavior and gender on green purchase intention. Journal of Retailing and Consumer Services, 41, 177189.

Struwig, M., \& Adendorff, C. (2018). Consumers' Perception of Eco-labels in South Africa. Athens Journal of Business \& Economics, 4(2), 163-178.
Tabachnick, B., \& Fidell, L. (2007), Using Multivariate Statistics. 5th ed. Pearson Education: USA.

Tung, O. J. L. (2016). Organic Food Certification in South Africa: A Private Sector Mechanism in Need of State Regulation? PER: Potchefstroomse Elektroniese Regsblad, 19(1), 1-48.

Wahba, G. H. (2012). Latest trends in environmental advertising design "application study of Egyptian society". Procedia - Social and Behavioral Sciences, 51, 901-907.

Wanjohi, P., Gachoka, H., Kihoro, J., \& Ogutu, M. (2013). Green business: potential for application as a business innovation for wealth and employment creation in Kenya. Global Business and Economics Research Journal, 2, 1-12.

Yazdanifard, R., \& Igbazua, E. M. (2011). The impact of Green Marketing on Customer satisfaction and Environmental safety. International Conference on Computer Communication and Management. IACSIT Press, Singapore.

Yong, A. G., \& Pearce, S. (2013). A Beginner's Guide to Factor Analysis: Focusing on Exploratory Factor Analysis. Tutorials in Quantitative Methods for Psychology, 9, 79-94. 